\title{
Historic tsunami in Britain since AD 1000: a review
}

\author{
S. K. Haslett ${ }^{1, *}$ and E. A. Bryant ${ }^{2}$ \\ ${ }^{1}$ Quaternary Research Centre, Department of Geography, School of Science and the Environment, Bath Spa University, \\ Newton Park, Bath, BA2 9BN, UK \\ ${ }^{2}$ Science Faculty Office, University of Wollongong, Wollongong, NSW 2522, Australia \\ * present address: CELT, University of Wales, Newport, Lodge Road, Caerleon, South Wales, NP18 3QT, UK
}

Received: 26 February 2008 - Revised: 4 June 2008 - Accepted: 4 June 2008 - Published: 30 June 2008

\begin{abstract}
The British coast is not considered at particular risk from tsunami, a view that is supported by a number of recent government reports. However, these reports largely ignore some written historic records that suggest southern Britain has experienced a number of events over the past 1000 yrs. This study briefly assesses these records and recognises four groups of events: 1) sea disturbance and coastal floods in southeast England linked to earthquakes in the Dover Straits (e.g. 1382 and 1580), 2) far-field tsunami reaching the coast of the British Isles, for example, from earthquakes along the Azores-Gibraltar Fault Zone offshore Portugal (e.g. 1755), 3) tsunami associated with near-coastal low magnitude earthquakes (e.g. 1884 and 1892), and 4) a flood event in AD 1014 that has been linked to comet debris impact. The seismogenic events range from minor water disturbance, through seismic seiching, to small and "giant" waves, suggesting near-coastal, low-magnitude, shallow earthquakes may be capable of triggering disturbance in relatively shallow water, as supported by similar occurrences elsewhere, and that the British tsunami risk requires a more careful evaluation.
\end{abstract}

\section{Introduction}

The coast of the British Isles has not been considered to be particularly at risk from the impact of tsunami. Nevertheless, in the aftermath of the Indian Ocean tsunami of 2004, a study commissioned by the Department of Environment, Food and Rural Affairs (DEFRA, 2005) evaluated the threat posed by

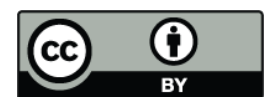

Correspondence to: S. K. Haslett (simon.haslett@newport.ac.uk) tsunami to the UK. The study concluded that, despite their stated view that UK seismicity "is of no possible relevance to tsunami hazard" (p. 9), "the most likely scenario for a significantly damaging tsunami in the UK is an anomalously large ... earthquake ... that would only be severe locally ... and even should such an event [earthquake] occur, it is probable that it would not produce a tsunami" (DEFRA, 2005, p. 3). The study does acknowledge the potential risk from a North Sea earthquake (similar to the 1931 Dogger Bank earthquake; see also DEFRA, 2006), a passive margin earthquake in the Celtic Sea region, a Storegga slide-type event (Smith et al., 2005), an earthquake on the Azores-Gibraltar fracture zone (similar to the 1755 Lisbon earthquake; Foster et al., 1991; Dawson et al., 2000; DEFRA, 2006), and flank failure of Canary Island volcanoes (e.g. Masson, 1996; Ward and Day, 2001).

DEFRA (2005) do evaluate and discount the recent theory proposing the catastrophic Bristol Channel flood of 1607in which it is thought 2000 people died-was caused by a tsunami (Bryant and Haslett, 2003, 2007; Haslett and Bryant, 2005, 2007a) rather than a storm (Horsburgh and Horritt, 2006). However, the tsunami risk in Britain is not considered beyond a few events (e.g. 1580, 1755, and 1931 earthquakes). The aim of this paper is to briefly assess written historic accounts that suggest a number of additional tsunami-like occurrences in Britain over the last $1000 \mathrm{yrs}$.

Recently, an earthquake occurred along the English Channel coast, with its epicentre at Folkestone in Kent, at 8.28 a.m. (local time) on 28 April 2007. The local earthquake magnitude was estimated by the British Geological Survey as $4.2 \mathrm{M}_{L}$ (Walker and Musson, 2007) and no discernable affect was reported on the sea. However, worryingly, a local news outlet reported that coastal residents on feeling the tremor "started rushing out from their houses and on to the

Published by Copernicus Publications on behalf of the European Geosciences Union. 
beach for safety" (Kent News, 2007)! This highlights the need to assess the threat from tsunami and associated hazards in Britain and, if appropriate, raise public awareness of the potential hazards.

\section{Tsunami-like Events}

Based upon definitions posted on the websites of NOAA, the International Tsunami Information Center (ITIC), and the Pacific Tsunami Warning Center (PTWC), a tsunami can be defined as a wave, or series of waves in a wave train, generated by the sudden, vertical displacement of a column of water. This displacement can be due to seismic activity, explosive volcanism, impulsive ground movement, landslides above or below water, an asteroid impact, or certain meteorological phenomena (Bryant, 2001). A tsunami can be generated in oceans, bays, lakes, rivers, or reservoirs. Events since AD 1000 have been selected for inclusion in the present study if there is a link between sea disturbance and/or flooding and a source (e.g. earthquake, comet). For this reason, catastrophic flooding events without an obvious source, such as the 1607 flood (Bryant and Haslett, 2003, 2007) and some other "non-tsunami" events catalogued by Long and Wilson (2007) e.g. 1759, 1811, 1843, 1859, 1869, have been omitted. Although we fully appreciate that historical documents may mis-report, exaggerate or even invent accounts, we have adopted an inclusive, but not uncritical, approach to the use of historic evidence in the first instance, so as not to dismiss material before it can be openly discussed. It is also appreciated that second-hand sources are likely to be less reliable than first-hand contemporary accounts and so these have been used wherever possible. It is not the purpose of this paper to present a new catalogue consistent in format with the New European Tsunami Catalogue, but only to present observational material that may support the future construction of such a catalogue. Figure 1 shows the locations of places mentioned in the text, and Table 1 summarises the events reviewed.

\subsection{Dover Straits events}

Davison (1924) presents contemporary accounts, including Holinshed (1587), of a strong earthquake with an estimated local magnitude, $\mathrm{M}_{L}$, of $5.75 \pm 0.25$ (Varley, 1996) that occurred on the 21 May 1382, which "was so vehement, and namelie in Kent, that the churches were shaken therewith in such wise, that some of them were ouerthrowen to the ground" (Holinshed, 1808, p. 754). There was then a second event on the 24 May when "earlie in the morning, chanced another earthquake, or (as some write) a watershake, being so vehement and violent a motion, that it made the ships in the havens to beat one against the other, by reason whereof they were sore bruised by such knocking together" (Holinshed, 1808, p. 754). Melville (1982), citing the contemporary
Chronicles of Henry Knighton (Martin, 1995), which is one of the sources undoubtedly used by Holinshed (1587), describes the event "as a water quake, which caused the ships in the ports to shake from the movement of the waves" (Melville, 1982, p. 131). The event of the 24 May occurred close to the time of predicted high tide at 09:52 GMT on the morning in question (Table 1). The direct link here between a seismic event and hazardous sea conditions in early summer, suggests that the sea was affected by seismic activity at this time, manifested either as a small tsunami or seiching within harbours. The intensity of this second earthquake is uncertain but was as strong as, or locally stronger than, the first (Melville et al., 1996).

Holinshed (1587) recounts another "watershake" at the arrival of Empress Anne of Bohemia in Dover, who was to later marry King Richard II, "where at hir landing, a maruelous and right strange woonder happened; for she was no sooner out of hir ship, and got to land in safetie with all hir companie, but that foorthwith the water was so troubled and shaken, as the like thing had not to any mans remembrance euer beene heard of: so that the ship in which the appointed queene came ouer, was terrible rent in peeces, and the residue so beaten one against an other, that they were scattered here and there after a wonderful manner" (Holinshed, 1808, p. 753). Although the date of Anne's landing at Dover is given as 18 December 1381 in the Dictionary of $\mathrm{Na}$ tional Biography (Gairdner, 1975), Lowes (1904) in examining a contemporary account in Thomas Walsingham's Historia Anglicana states that the event "is not definitely stated by Walsingham to have been due to a storm of wind" and that it "was probably the result of an earthquake" (p. 242). Moreover, Lowes (1908) gives the general impression from his reading of contemporary sources that the event was seen to be "a strange and unprecedented disturbance of the sea" (p. 289). Although occurring within a general period of seismic activity in the area, there is no record of an earthquake associated with this event leaving its origin somewhat enigmatic.

An earthquake certainly occurred later in the English Channel on 23 April 1449 and caused "boats [to be] rocked up and down" and it is claimed "the sinking of many ships" in Belgium, but appears not to have affected southeast England (Melville et al., 1996, p. 633). Other than this, however, little appears to be known about the circumstances of the event and the magnitude of the earthquake.

Two large earthquakes occurred $12 \mathrm{~h}$ apart on 6 and 7 April 1580 affecting a large area of southeast England, northeast France and Belgium (Mansergh, 1891), and were probably generated along the Kent-Artois shear zone beneath the English Channel. The earthquakes had an estimated local magnitude, $\mathbf{M}_{L}$, of 5.8 (Musson, 1994, 2003). An unusual feature of the first event is the duration of ground shaking, with contemporary accounts estimating from six or seven minutes (Melville, 1981) to eight minutes (Ellart and Vion, 1991), and in places three or four ground waves were seen 


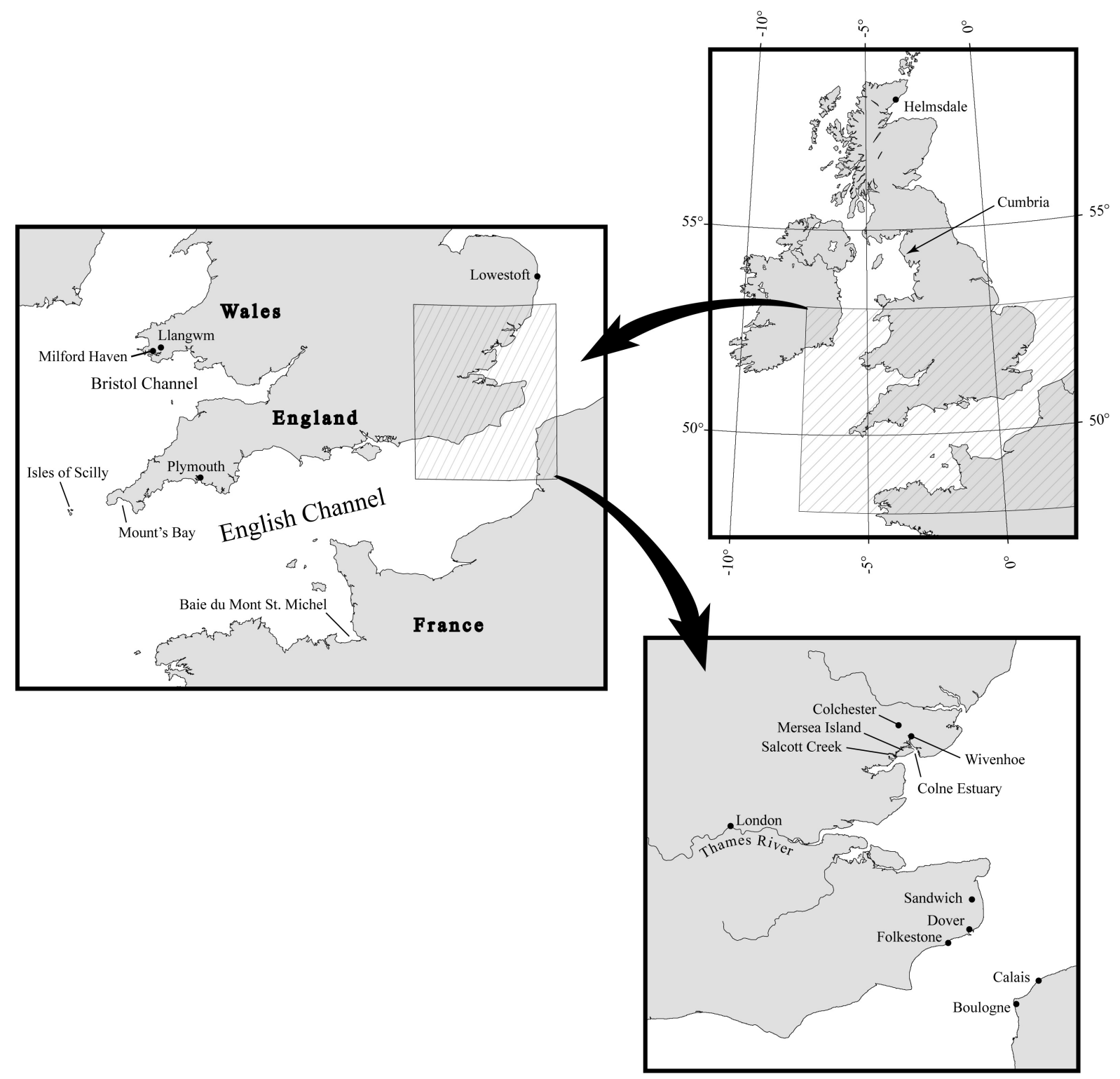

Fig. 1. Locations of places mentioned in the text.

propagating across the landscape like "waves in the water, rolling forwards" (Melville, 1981, p. 373). Such shaking was capable of initiating landslides as exemplified at Dover where a section of Chalk cliff collapsed into the sea taking with it part of Dover castle (Fig. 2; Melville, 1981; Melville et al., 1996).

A number of large tsunami ("giant waves" or seismic sea-waves as described by some authors) were apparently produced that proved very destructive and possibly caused several hundred fatalities (Melville, 1981; Ambraseys and Melville, 1983; Neilson et al., 1984; Varley, 1996). A new translation of a contemporary French account presented here states:
"Now to come to the marvellous things which have occurred in this month of April, one thousand five hundred and eighty, on the sixth and seventh day, I can assure you that in the city of Calais such a horrible and terrible earthquake did come to pass that a great part of the houses fell, and even the sea overflowed into the city and did ruin and drown a great number of houses, and numerous persons perished, and a great multitude of beasts lost which were at pasture outside this city. Mention hath been made of several ships that perished by the great and awful tempestuousness of the sea, which number up to twenty-five, or thirty, French, English and Flemish vessels, and this was done between Calais and Dover. One passenger that came from Dover to Calais relates that his ship did touch the bottom of the sea five times, 
Table 1. Summary of events reviewed. GMT=Greenwich Mean Time (Myers, 2007); HW=high water. ${ }^{1}$ Tidal predictions supplied by the UK Hydrographic Office.

\begin{tabular}{|c|c|c|c|c|c|}
\hline $\begin{array}{l}\text { Date and Time } \\
\text { (Julian and } \\
\text { [Gregorian]) }\end{array}$ & Tsunami Source & $\begin{array}{l}\text { Time of nearest high tide(s) (and } \\
\text { height, } m \text { above Chart Datum) }\end{array}$ & Areas affected & Deaths (in Britain) & Other impacts \\
\hline 28 September [8 October] 1014 & Comet impact (?) & $\begin{array}{l}\text { Dover, } 8 \text { October: HW 01:27 }(6.6 \mathrm{~m}) \\
\text { and 13:50 }(6.5 \mathrm{~m}) \mathrm{GMT} \\
\text { Dover, } 9 \text { October: HW 02:10 }(6.3 \mathrm{~m}) \\
\text { GMT } \\
\text { Penzance (Newlyn), } 8 \text { October: HW } \\
07: 21(5.2 \mathrm{~m}) \text { and } 19: 40(5 \mathrm{~m}) \mathrm{GMT} \\
\text { Whitehaven (Cumbria), } 8 \text { October: } \\
\text { HW 02:06 (7.6m) and 14:28 (7.5 m); } \\
9 \text { October: } 02: 52(7.3 \mathrm{~m})\end{array}$ & $\begin{array}{l}\text { Kent, Sussex, Hampshire, } \\
\text { Cornwall, Cumbria (?) }\end{array}$ & $\begin{array}{l}\text { unknown, but reference to } \\
\text { drowning throughout area }\end{array}$ & $\begin{array}{l}\text { "submerge villages many miles inlan" William of } \\
\text { Malmesbury (Mynors et al.,1998) } \\
\text { "ran so far up as it never did before, overwhelm- } \\
\text { ing many towns" Anglo-Saxon Chronicle (Ingram, } \\
\text { 1823) } \\
\text { "inundated by a "mickle seaflood" when many } \\
\text { towns and people were drowned" (Saundry, 1936) } \\
\text { "much people and cattle lost" (Meldola and White, } \\
\text { 1885) }\end{array}$ \\
\hline 1247 & earthquake & & Kent & None known & $\begin{array}{l}\text { the sea is said to have "ceased to ebb and flow" } \\
\text { (Ritchie, 1991, p. 37) }\end{array}$ \\
\hline 18 [26] December 1381 & & unknown & Kent & None known & Ships destroyed at the port of Dover \\
\hline $\begin{array}{l}24 \text { May [3 June] 1382, morning } \\
\text { local time }\end{array}$ & $\begin{array}{l}5.75 \pm 0.25 \mathrm{M}_{\mathrm{L}} \text { earthquake, proba- } \\
\text { bly in the English Channel }\end{array}$ & $\begin{array}{l}\text { Dover, } 3 \text { June: HW 09:52 (6.3 m) } \\
\text { GMT }\end{array}$ & Kent & unknown & $\begin{array}{l}\text { "ships in the havens to beat one against the other" } \\
\text { (Holinshed, 1587) } \\
\text { "ships in harbour were tossed by the shock" } \\
\text { Knighton's Chronicle (Martin, 1995,p. 243). }\end{array}$ \\
\hline 23 April [2 May] 1449 & earthquake & & English Channel & None known & $\begin{array}{l}\text { "boats rocked up and down" (Melville et al., 1996, } \\
\text { p. 633) } \\
\text { "the sinking of many ships" (Melville et al., 1996, } \\
\text { p. 633) }\end{array}$ \\
\hline \multirow{2}{*}{$\begin{array}{l}6 \& 7[16 \& 17] \text { April } 1580 \text {, ca. } \\
4.30 \text { p.m. and } 4.30 \text { a.m. local } \\
\text { time respectively }\end{array}$} & $\begin{array}{l}5.8 \mathrm{M}_{\mathrm{L}} \text { earthquakes in the English } \\
\text { Channel }\end{array}$ & $\begin{array}{l}\text { Dover, } 16 \text { April: HW 15:25 }(5.7 \mathrm{~m}) \\
\text { GMT }\end{array}$ & $\begin{array}{l}\text { Kent and northeast coast } \\
\text { France }\end{array}$ & $\begin{array}{l}120 \text { at Dover, but other in } \\
\text { France }\end{array}$ & See text for French accounts. \\
\hline & & $\begin{array}{l}\text { Dover, } 17 \text { April: HW 04:12 (5.5 m) } \\
\text { GMT }\end{array}$ & & $\begin{array}{l}165 \text { ships sank, presumably } \\
\text { with loss of life }\end{array}$ & $\begin{array}{l}\text { "The ships quaked and trembled as the houses on } \\
\text { drye land, and the waters were greatly out of tem- } \\
\text { per" (Munday, 1580, p. } 32 \text { ) } \\
\text { "The shippes in the seae, as also such as weare at } \\
\text { the keye and wythin the havon at the beacons, felte } \\
\text { the lyke [earthquake]" (Boys, 1792, p. 696) } \\
\text { "even the sea was thrown into such turbulence } \\
\text { that sailors cleaving the main feared submergence } \\
\text { forthwith" Registrum Annalium Collegii Merto- } \\
\text { nensis, 1567-1603 (Melville et al., 1996, p. 67) } \\
\text { "the land not onlie quaked, but the sea also } \\
\text { fomed, so that the ships tottered" (Holinshed, } \\
1808 \text {, p. } 426 \text { ) } \\
\text { "at the same instant of time [as the earthquake], as } \\
\text { 'twas generally supported, the sea was so much } \\
\text { tossed and troubled, that the Mariners expected } \\
\text { sudden destruction" (Wood, 1796, p. 199) }\end{array}$ \\
\hline 1 November 1755 & $\begin{array}{l}8.7 \mathrm{Mw} \text { magnitude earthquake, } \\
\text { Azores-Gibraltar Fracture Zone }\end{array}$ & See Dawson et al. (2000) & $\begin{array}{l}\text { Atlantic-coast of Europe, } \\
\text { southwest Britain, English } \\
\text { Channel, southern North } \\
\text { Sea, Ireland. }\end{array}$ & $\begin{array}{l}\text { None known in southern } \\
\text { Britain. }\end{array}$ & No details known from southern Britain. \\
\hline 31 March 1761 , ca. 5 p.m. & $\begin{array}{l}7.5 \text { Ms earthquake, offshore Portu- } \\
\text { gal }\end{array}$ & $\begin{array}{l}\text { Penzance, } \\
\text { Cornwall: HW 13:36 (4.1 m) GMT }\end{array}$ & $\begin{array}{l}\text { Atlantic-coast of Europe, } \\
\text { southwest Britain, Ireland }\end{array}$ & None & $\begin{array}{l}\text { A succession of waves observed in Mounts Bay, } \\
\text { Cornwall }\end{array}$ \\
\hline 28 November 1776 & earthquake & & Calais, northeast France & None known & The sea withdrew at Calais \\
\hline 9/10 August 1802 & Distant earthquake (?) & & Dorset and Devon & None & $\begin{array}{l}0.35 \text { and } 0.6 \mathrm{~m} \text { high at Weymouth and Teignmouth } \\
\text { respectively }\end{array}$ \\
\hline 7 March 1831 & Earthquake & & Kent & None & $\begin{array}{l}\text { the tide at Dover "flowed full half-an-hour earlier } \\
\text { than the calculated time" (Kentish Gazette, 1831, } \\
\text { p. 2) }\end{array}$ \\
\hline 23 May 1847 , all day and evening & Earthquake, near Isles of Scilly (?) & & Devon and Cornwall & None & Waves up to $1.5 \mathrm{~m}$ came ashore \\
\hline 21 October 1859 & $4.0 \mathrm{M}_{\mathrm{L}}$ & earthquake, offshore North Cornwall & Cornwall and Devon & None & Local water disturbance \\
\hline 22 April 1884, 09:18 a.m. GMT & $\begin{array}{l}4.6-5.5 \mathrm{M}_{\mathrm{L}} \text { earthquake, epicentre } \\
\text { near Colchester, Essex }\end{array}$ & $\begin{array}{l}\text { Brightlingsea, } \text { Essex: } \\
\text { 09:15 (4.3 m) GMT } \\
\text { Margate, Kent: HW } \\
\text { GMT } \\
\text { London Bridge: } \\
\text { GMT }\end{array}$ & $\begin{array}{l}\text { Suffolk, Essex, Thames, } \\
\text { north Kent }\end{array}$ & $\begin{array}{l}\text { None known, although } \\
\text { many injuries }\end{array}$ & $\begin{array}{l}\text { boats shaken, up to } 1 \mathrm{~m} \text { high wave in the Colne } \\
\text { and Thames estuaries } \\
\text { bottom sediments disturbed }\end{array}$ \\
\hline 18 August $1892,0.24 \mathrm{am}$ GMT & $\begin{array}{l}5.1 \mathrm{M}_{\mathrm{L}} \text { earthquake, epicentre off- } \\
\text { shore south Pembrokeshire }\end{array}$ & $\begin{array}{l}\text { Milford Haven: HW 02:05 }(5.4 \mathrm{~m}) \\
\text { GMT }\end{array}$ & $\begin{array}{l}\text { Pembrokeshire, but earth- } \\
\text { quake felt as far afield as } \\
\text { Surrey, the Isles of Scilly, } \\
\text { Rhyl (North Wales), and Car- } \\
\text { low (southern Ireland) }\end{array}$ & None & three tsunami progressed up Milford Haven \\
\hline $\begin{array}{l}24 \text { January } 1927,05: 30 \text { a.m. } \\
\text { GMT }\end{array}$ & $\begin{array}{l}5.7 \mathrm{M}_{\mathrm{L}} \text { earthquake, Viking } \\
\text { Graben (North Sea) }\end{array}$ & & Eastern Scotland & None & $\begin{array}{l}\text { Tyrell (1932) reports that "at the time of the shock } \\
\text { the bar at the mouth of the Helmsdale River [in } \\
\text { eastern Scotland] was calm, but at } 5.30 \mathrm{am} \text { great } \\
\text { rollers began to come in from the south-east". }\end{array}$ \\
\hline 25 November 1941 & $\begin{array}{l}\text { 8.2 Ms earthquake, offshore Portu- } \\
\text { gal }\end{array}$ & & English Channel & None & $\begin{array}{l}0.2 \mathrm{~m} \text { high on Newlyn (Cornwall) tide gauge, and } \\
\text { registered at Le Havre (France) }\end{array}$ \\
\hline 24 May 1960 & 9.6 Mw earthquake, offshore Chile & & Cornwall & None & Registered on Newlyn (Cornwall) tide gauge \\
\hline 28 February 1969 & $\begin{array}{l}\text { 7.3 Ms earthquake, offshore Portu- } \\
\text { gal }\end{array}$ & & Cornwall & None & Heavy seiching at Newlyn, Cornwall \\
\hline 26 May 1975 & $\begin{array}{l}\text { 7.9 Ms earthquake, offshore Portu- } \\
\text { gal }\end{array}$ & & Cornwall & None & $0.06 \mathrm{~m}$ high on Newlyn (Cornwall) tide gauge \\
\hline 27 December 2004 & $\begin{array}{l}9.3 \mathrm{Mw} \text { earthquake, offshore } \\
\text { Sumatra }\end{array}$ & & English Channel & None & $\begin{array}{l}\text { Registered on tide gauges in the English Channel } \\
\text { and possibly Milford Haven }\end{array}$ \\
\hline
\end{tabular}


and the waves mounting higher than six heights of a spear above his ship: but God preserved him. Several who crossed from England, leaving from the port of Dover, made mention that they thought themselves lost, and that there were similar shakings that way beyond the sea: even on Thursday the vii day of this month of April, in the morning between four and five o'clock in these parts there were great signs of deluge, and the whole people thought they were in peril, and in a village near the port thirty houses fell, and as much as six score persons were lost and drowned by the flood ... At Boulogne the same quake and overflowing of the sea came to pass, and damaged a great part of the city and surroundings." (Discourse, 1580).

The second "deluge" also coincided with an earthquake observed in England (Neilson et al., 1984; Melville et al., 1996) and, therefore, there is an extremely close association between earthquakes and floods in this account. Both of these events occurred probably close, if not coincident in the case of the second event, with the time of high tide (Table 1), which would have enhanced the effect of any tsunami coming ashore. The effect of these earthquakes on the sea along the English coast was startling to observers, but appears less extreme than the impacts documented in northern France. This may not be unexpected as Melville (1981) places the earthquake epicentre closer to the French coast. Table $1 \mathrm{com}-$ piles five separate contemporary English 1580 accounts, two of which describe severe sea conditions with sailors battling for their lives. Further along the French coast at Dunkerque, Melville et al. (1996) recount that "the ground swelled underfoot and towers and houses shook as well as the ships at sea" (p. 637), and even as far away as The Netherlands coast reports of "fish being thrown ashore ... and ships rising on the sea as though they were dancing" (p. 638) supports the severity of the event.

Significant confusion exists regarding this event as DEFRA (2005), citing Melville et al. (1996), consider the flooding to be caused by a violent hurricane stating "that contemporary sources conflated descriptions of the earthquake with the effects of a storm that occurred very shortly afterwards" and that "to a 16 century writer it would have been natural to consider the seismic shock and a storm a day later as being part of the same occurrence" (p. 11). This may be true, except the storm in question occurred not a day later but a year later in March 1581 (Melville et al., 1996). Therefore, the DEFRA (2005) report is misinformed and underestimates the contemporary accounts. This is particularly so as at least three contemporary accounts, cited by Melville et al. (1996), describing the earthquakes and associated flooding were published in 1580, that is, before the storm with which the flooding is supposed to be confused. Moreover, Neilson et al. (1984) in an extensive review of the 1580 earthquake state, "all [contemporary] accounts agree that at the time of the earthquake the weather was fine and calm" (p. 117).

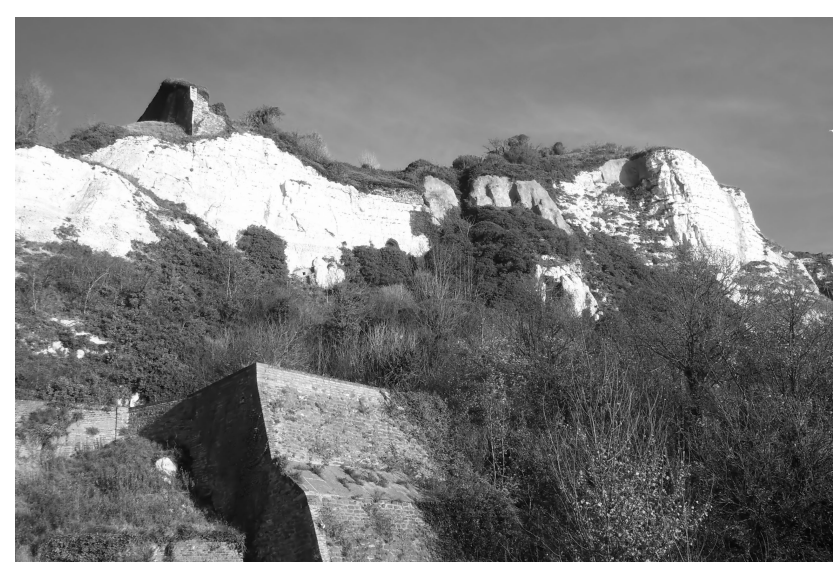

Fig. 2. East Cliff at Dover (Kent) showing the wall of Dover Castle truncated by cliff collapse. The Castle wall and cliff here are reported to have collapsed during the 1580 Dover Straits earthquake.

The only possible confusion with meteorological conditions is the statement that "near Mont Saint Michel 15 [ships] were lost, and a great tempest arose and some signs appeared: it is said that fire fell from heaven and damaged several places, and did even burn some quantity of the woods that are two leagues from the town of Mont Saint Michel" (Discourse, 1580). This appears to be a localised event with distinct differences to the other passages of the document in that for Dover, Calais and Boulogne the flooding is explicitly linked to the earthquake within the immediate text, whereas the damage suffered around Mont Saint Michel is more clearly related to the "great tempest [that] arose". In this context, the fire from heaven is more likely to be lightening rather than a comet, suggesting that an isolated thunderstorm is being described and, considering the distance, is likely to be unrelated to the Dover Straits events.

Other earthquakes that may have had some effect on the sea in the area include 1247 when associated with an earthquake the sea is said to have "ceased to ebb and flow" (Ritchie, 1991, p. 37), 28 November 1776 for which Melville et al. (1996) report a contemporary account that states that "soon after the earthquake was over at Calais, the sea retired upwards of a mile and half from the town, and many thousands of fish were taken alive by the hands of the inhabitants" (p. 644), and 7 March 1831 when associated with an earthquake the tide at Dover "flowed full half-an-hour earlier than the calculated time" (Kentish Gazette, 1831, p. 2).

\subsection{Far-field tsunami}

A number of earthquakes along the Azores-Gibraltar Fracture Zone have generated tsunami that have come ashore in Britain. The Lisbon earthquake of 1 November 1755 , estimated to have a moment magnitude, $\mathrm{M}_{W}$, of $8.7 \pm 0.39$ (Johnston, 1996), generated tsunami that caused much damage and fatalities in Portugal and the surrounding region. 


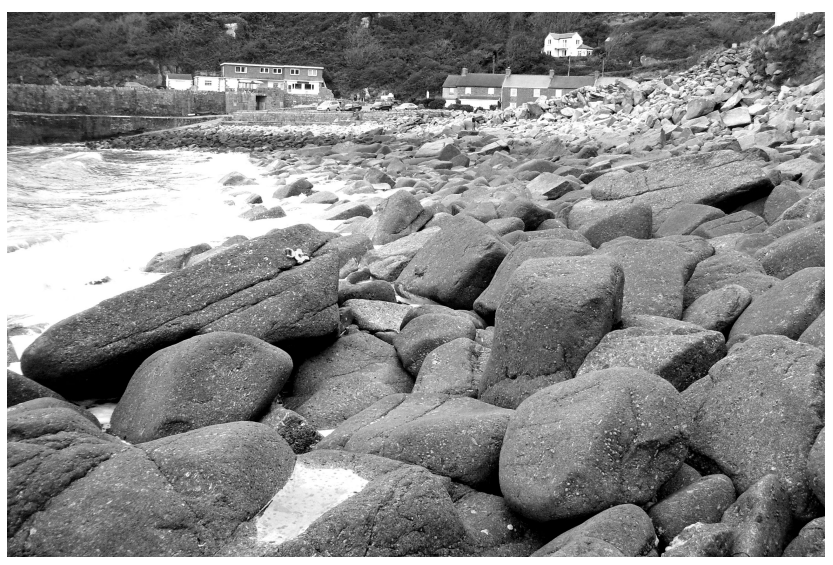

Fig. 3. The boulders of Lamorna Cove (Cornwall) are reported to have been moved by the 1755 Lisbon earthquake generated tsunami. Analysis has shown that the boulders have been moved subsequently by storm waves.

The tsunami also propagated northwards to strike the coast of Brittany, southern Ireland and southwest Britain (e.g. McGuire, 2005). Foster et al. (1991) and Dawson et al. (2000) examine accounts of the tsunami's impact in southwest Britain recounting the arrival of four waves in Mount's Bay (Cornwall) over a period of two hours, sand sheets deposited at Stonehouse Creek, Plymouth (Devon), and in Big Pool on St. Agnes in the Isles of Scilly, and the transport and deposition of boulders in a stream ca. $3 \mathrm{~m}$ above the high tide limit at Lamorna Cove, a site near Mount's Bay in west Cornwall. This observation suggests a local tsunami run-up of ca. $6 \mathrm{~m}$ OD (Ordnance Datum Newlyn). We undertook field visits to these named sites in October 2007.

Sediment coring at Big Pool confirmed the presence of a substantial sand layer as recorded by Foster et al. (1991, 1993), although based on the error bars of their dating the 1755 event is not the only candidate for its deposition (Haslett and Bryant, 2007a). Stonehouse Creek was found to have been infilled during the 19 century with several meters of rubble for the development of recreational and sports fields (e.g. Victoria Park, opened in 1902). It was not possible to penetrate this rubble using manual coring techniques. Boulders were measured at Lamorna Cove (Fig. 3) and analysed using equations by Nott (2003) to determine the wave height required to transport them. Large boulders, in excess of $40 \mathrm{t}$, found on the beach possessed mechanical marks and were clearly derived from a portion of the harbour wall that was broken during a storm in the 1960's and subsequently transported onshore. Minimum storm wave heights required to move these boulders are estimated at $18.5 \mathrm{~m}$, equivalent to a tsunami wave height of $4.6 \mathrm{~m}$. Given that the 50-yr maximum storm wave height is ca. $20 \mathrm{~m}$ in southern Cornwall (NERC, 1991), and the highest tsunami arriving in Mount's Bay in the 1755 event was recorded at ca. $2.4 \mathrm{~m}$ (Davison,
1924), it is likely that any tsunami signatures from the 1755 event, other than sand layers preserved in back-barrier settings, would have been lost or "overprinted" due to subsequent intense storm activity.

Dawson et al. (2000) indicate that "there are no known reports of the progress of this tsunami NE along the English Channel" (p. 61), and DEFRA (2006) do not include the English Channel or North Sea in their models. However, Bryant (2001) does mention reports of the seiching or tsunami-like activity in the English Channel and the North Sea coast of the Netherlands, where descriptions exist depicting hazardous seas and the loss of vessels (Leenders, 2000; Earthquake Engineering Research Centre, 2005). Also, a second-hand report describes a tsunami-like wave coming ashore on the English coast of the North Sea on the same day (Fitch, 1884).

Long and Wilson (2007) catalogue other tsunami that have reached the British coast from a similar seismic source offshore Portugal. These include a $1.2 \mathrm{~m}$ high tsunami in 1761 , $0.35-0.6 \mathrm{~m}$ tsunami in $1802,0.2 \mathrm{~m}$ tsunami in 1941 , minor water disturbance in 1969, and a $0.06 \mathrm{~m}$ tsunami in 1975 . There is no question over the relationship between seismic activity and tsunami generation here, and that earthquakes and their associated tsunami originating from this region present a credible future risk for the British coast. Their inclusion in the risk assessments of DEFRA $(2005,2006)$ are, therefore, entirely justified.

Another tsunami appears to have come ashore in Mount's Bay on Sunday 23 May 1847, however, this time it is likely to be associated with a relatively high magnitude earthquake felt at the time in the Scilly Isles (Musson, 1989). DEFRA (2005) and Long and Wilson (2007) mention this event with reference to a later recounting of the event by Edmonds (1869) and state that the waves were up to $1.5 \mathrm{~m}$ high, although Long and Wilson (2007) classify this event as "an uncertain tsunami event".

However, we present here a contemporary description that leaves little doubt that the event was a tsunami:

"on Sunday evening last [23 May] a very extraordinary commotion of the sea took place in this bay, which was observed by a great number of persons. About half-past 5 o'clock it made a rush on to the beach for 50 or 60 feet, and immediately receded to its natural position. This occurred a great many times up to half-past 8 . The boats at Newlyn and Penzance [in Mount's Bay] were sometimes afloat, and then again almost dry; those that were at the moorings in Gwavaslake [a sea cove] all showed their heads towards the effing, although the wind at the time was blowing very strong off the land. A schooner at anchor off this pier-head was noticed to go completely round several times" (The Times, 1847, p. 6).

Other far-field tsunami are also catalogued by Long and Wilson (2007) including the 1960 Chilean and 2004 Indian Ocean tsunamis detected on British tide gauges. Closer to Britain, on 24 January 1927, a $5.7 \mathrm{M}_{L}$ magnitude earthquake occurred beneath the Viking Graben in the North Sea. 
Tyrell (1932) reports that "at the time of the shock the bar at the mouth of the Helmsdale River [in eastern Scotland] was calm, but at 5.30 a.m. great rollers began to come in from the south-east". Both DEFRA (2005) and Long and Wilson (2007) discount the possibility that the rollers were tsunami because Helmsdale is $400 \mathrm{~km}$ from the earthquake epicentre and it is "inconceivable that waves originating in the Viking Graben could have reached Helmsdale in only 12 min" (DEFRA, 2005, p. 11). DEFRA (2005) rules out the possibility that a submarine slide was responsible "given the relative lack of topography in the shallow waters of the North Sea" (p. 10). However, without a detailed evaluation a source closer to shore remains a candidate, particularly as the reported weather was unexceptional, and that Ambraseys and Melville (1983) report that two cables laid on the bed of the North Sea, since the late nineteenth century, have been severed during earthquakes, probably indicating submarine slide activity.

\subsection{Near-coastal low-magnitude seismic events}

A number of relatively low-magnitude earthquakes occurring close to the coast appear to have generated tsunami in nearcoastal waters. In eastern England, an earthquake occurred at 9.18 a.m. on 22 April 1884 with its epicentre near Colchester, Essex, but was felt up to $290 \mathrm{~km}$ away. Estimates of local magnitude, $\mathrm{M}_{L}$, range from 4.6 (Musson, Neilson and Burton, 1990; Musson, 2003) to 5.5 (Scott, 1977). Although the epicentre was onshore, contemporary accounts clearly describe a tsunami propagating along the Colne Estuary and out into the coastal waters. In the Colne Estuary "a resident of Wivenhoe (Fig. 4) says it was high tide when the shock [earthquake] was felt. Vessels [boats] reared up two or three feet [up to ca. $1 \mathrm{~m}$ ] out of the water" (Evening Standard, 1884, p. 2). Fishermen at sea off the coast, presumably offshore Mersea Island in the mouth of the Colne Estuary, "describe the appearance of the sea as suddenly rising and suddenly falling again, leaving them, as it were, in a hollow of the water" (Colchester Gazette, 1884, p. 2), a description that suggests they suddenly found themselves in the trough of a long-period tsunami wave. However, perhaps the most convincing observation that a tsunami was generated by this earthquake appeared the following day in the Eastern Daily Press newspaper where "the sea is said to have rushed with restless force over the marshes [of East Mersea Island], receding some time afterwards, leaving thick deposits of sand behind, in some instances at incredible distances from the coast" (Musson et al., 1990). Such a description is common to tsunami coming ashore and the deposition of a sand layer is a frequent signature of tsunami (Bryant, 2001). Contrary to the impression given by these contemporary reports, a later review of the event by Meldola and White (1885) states that "the absence of any distinct movement of the river [Colne] was generally confirmed" (p. 91);

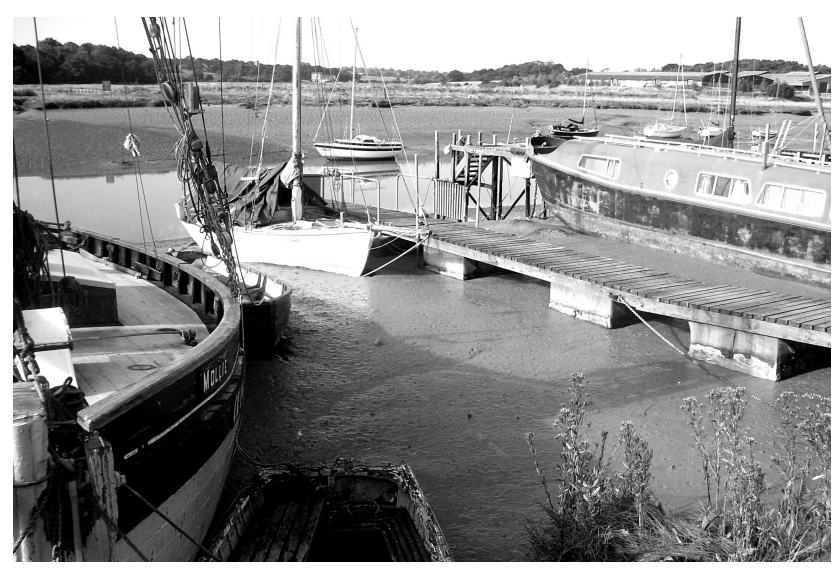

Fig. 4. The Colne Estuary at Wivenhoe (Essex) affected by the 1884 Colchester earthquake.

however, in reaching this conclusion, they omit or are unaware of the reports we present above, which leaves their conclusions highly questionable.

It seems that the occurrence of a tsunami associated with this earthquake was widely appreciated at the time as, for example, the Liverpool Mercury in their extensive account of the impacts of the earthquake stated that, associated with the earthquake, "a tidal wave on a small scale visited the coast of Essex" (1884, p. 5). Elsewhere, a ca. $1 \mathrm{~m}$-high wave was reported to have occurred locally in the River Thames in London. Meldola and White (1885) state "a wave, estimated to have been about three feet high [ca. $1 \mathrm{~m}$ ], was seen to cross the river [Thames], and to cause a vessel lying at St. Pauls Pier to roll heavily without any apparent cause" (p. 147). Meldola and White (1885) are suspicious of this report and fail to find any record of water disturbance in tide gauges at Gravesend and Sheerness (Kent). This may not be surprising, however, as these locations are located approximately 30 and $50 \mathrm{~km}$ away respectively from central London where the wave was observed locally.

The earthquake was described by many observers as a ground wave that propagated away from its epicentre (Meldola and White, 1885). The amplitude of the wave appears to have been significant as one observer estimated (based on field measurements) an amplitude of $2 \mathrm{~m}$, however, this was dismissed by Meldola and White (1885) as being an extreme over-estimation. A more conservative estimation is given by Clark (1884) who states "the fact that it was a true [ground] "wave" has been shown in many curious ways ..." "the mate of a vessel at Wyvenhoe" who "happened to be standing upon the "Hard" [quay], ... looking across the level saltmarshes, he says he distinctly saw the movement [ground wave] advance towards him "like the wind passing over a field of corn, only quicker..." A boat builder was able to see through opposite windows in his workshop from the ground outside. Measurements show that the ground beneath him must have lifted at least $2 \mathrm{ft} 9$ in [ca. $0.8 \mathrm{~m}$ ]" $(84-85)$. It is 
highly probable that this too is an overestimation, but the coastal setting of any ground motion provides an impulsive seabed displacement mechanism for the excitation of a small local tsunami (Nosov and Skachko, 2001; Miloh et al., 2002; Yanovskaya et al., 2003).

The 1884 earthquake and/or tsunami appears also to have disturbed anoxic coastal and estuarine bottom muds and apparently entraining them in suspension, for at Tillingham, Essex, close to the coast, Haining (1976) states that residents described a "sulphurous vapour" occurring immediately after the earthquake (p. 123), and at Salcott Creek near Wigborough it was reported that "when the tide came in the water was black, thick and foul smelling and everywhere it left dead fish. The water remained black for several days" (p. 202). The mechanism for such sediment disturbance and entrainment may include the submarine propagation of the ground waves observed on land, submarine slides triggered by the earthquake, or tsunami passage.

Davison (1924) reports a relatively low-magnitude earthquake occurring on 18 August 1892 at 00.24 a.m. in the Bristol Channel near the Pembrokeshire coast. Musson (2006) estimates a local magnitude, $\mathrm{M}_{L}$, of 5.1 for the main earthquake that occurred about $1.5 \mathrm{~h}$ before the time of high tide (Table 1). At "Bulwell, on the southern shore of Milford Haven, two or three waves were seen to run up the shore, the sea both before and after being absolutely still" (Davison, 1924, p. 186). A steamboat further up-estuary near Llangwm reported that "the water, although perfectly calm before, became suddenly swelled ... the boat seemed as if it passed over three waves, after which the water ... became calm as before" (p. 186). From these observations it seems that a train of three seismogenic tsunami were generated by this earthquake. Then about one and a quarter hours later, an aftershock "was accompanied by a wave, but not nearly so marked as those seen at the time of the principal earthquake" (p. 187). Sea disturbance also appears to have affected the Bristol Channel with a number of reports stating that fishing vessels outside Milford Haven experienced "terrible" agitation (Daily News, 1892; Freeman's Journal, 1892).

On the English Channel coast of southwest England, the Penny Illustrated (1892) newspaper connects this earthquake with "a series of tidal waves" in the estuary of the river Yealm (Devon) where "a good deal of damage was done to boats moored in the river" (p.6). The Times (1892a) also reports this event in the river Yealm as well as stating that "about the time of the earthquake there was a rapid rise in the River Fowey [an estuary in Cornwall] as a great tidal wave, but this immediately subsided" (p. 4). Davison (1924) does not believe that the waves observed in Milford Haven and those along the south coast of Devon and Cornwall are linked. Indeed, The Times (1892b) report thunderstorms in the English Channel on the 18 August that may have spawned meteorological tsunami (Montserrat et al., 2006) along the English Channel coast, as later occurred with tragic consequences at Folkestone in July 1929 (Douglas, 1929).
Lastly, within this section, Dawson et al. (2000) express some surprise that an earthquake with an estimated local magnitude, $\mathrm{M}_{L}$, of 4.0 offshore North Cornwall on 21 October 1859 produced water disturbance at the coast despite the relatively low magnitude of the event.

\subsection{Cosmogenic tsunami?}

On 28 September 1014 widespread coastal flooding occurred in Britain. William of Malmesbury in The History of the English Kings (vol. 1) states that "a tidal wave, of the sort which the Greeks call euripus and we ledo, grew to an astonishing size such as the memory of man cannot parallel, so as to submerge villages many miles inland and overwhelm and drown their inhabitants" (Mynors, Thomson and Winterbottom, 1998, p. 311). In the subsequent passage Malmesbury refers to the great council at Oxford between the Danes and English that took place in the following year, which is $\mathrm{AD} 1015$, so the "tidal wave" he refers to occurred in AD 1014.

For the same year, the Anglo-Saxon Chronicle states that "on the eve of St. Michael's Day [28 September], came the great sea-flood, which spread wide over this land, and ran so far up as it never did before, overwhelming many towns, and an innumerable multitude of people" (Ingram, 1823). Some accounts suggest that this flood affected Kent, Sussex, Hampshire (Green, 1877), and even as far west as Mount's Bay in Cornwall, where the Bay was "inundated by a 'mickle seaflood' when many towns and people were drowned" (Saundry, 1936). Interestingly, Healy $(1995,1996)$ describes organic deposits in Marazion Marsh, that lie behind a coastal barrier in Mount's Bay, that is dated to no later than AD 980 and overlain by a sand layer, which could be a signature of the flood event.

Also, Short (1746) reports in a list of earthquakes that in 1014 "in Cumberland [Cumbria on the northwest coast of England]; much people and cattle lost" (cited in Meldola and White, 1885, p.4). Musson (2005) and other scholars consider all pre-1019 earthquakes listed by Short (1746) as fake because no contemporary accounts exist that corroborate his list. This may well be the case, but the coincidence, which it may just be, with a disaster in 1014 suggests that if this record is derived from some now lost source, and is not referring to an earthquake, it is conceivable that it relates to another type of hazard and should be considered. This could include coastal flooding in the extensive coastal lowlands of the Solway Firth and Morecombe Bay of Cumbria where flooding may result in the loss of livestock and people. In North Wales, it has been suggested that recently described field evidence for tsunami impact may be related to this event (Haslett and Bryant, 2007b). The flood is also mentioned in the Chronicle of Quedlinburg Abbey (Saxony), where it states many people died as a result of the flood in The Netherlands, and it is remembered in a North American account by Johnson (1889). 
Although speculative, this collection of records conspire to suggest a significant event(s) occurred in 1014 affecting a number of locations around the British Isles (southeast England, Cornwall, possibly Cumbria) and, if a single event, is unlikely to be a storm surge as they are usually more restricted. The event has characteristics of a tsunami given the geography and apparent severity of the flood. Indeed, Baillie (2007) considers the 1014 flood to have been a tsunami caused by a comet, or comet debris, impact(s). He cites GRIP ice core data indicating that the highest ammonium spike within the historic period occurs in 1014 and that the investigations of Comet Hale-Bopp, and others, show that ammonium is a major component (1-2\%) of comet composition. His theory is supported by another high ammonium anomaly recorded in the GISP2 ice core data coincident with the 1908 Tunguska bolide over Siberia. Also, myths and legends of native people from the North Atlantic region contain reference to comet-like occurrences (e.g. Nowlan, 1983) that require consideration. Furthermore, preliminary modelling indicates that a tsunami generated offshore northwest Europe in the North Atlantic could affect all the areas discussed above (Fig. 5). This event clearly requires further investigation.

\section{Discussion}

It appears from this brief review that the coast of Britain has over the past ca. $1000 \mathrm{yrs}$ experienced a number of seismogenic events that have affected the sea, and another possibly due to comet impact. Clearly all these events should be considered in evaluating the tsunami risk around the coasts of Britain and that the omission by DEFRA (2005) of a number of these events is puzzling, especially since some appear to have caused damage and claimed lives. The mechanism for triggering tsunami in these cases is not always clear or conforms to conventional understanding of the hazard; however, such difficulty should not be cited as reason to discount observations out of hand without further consideration.

It is accepted by many that an earthquake requires a magnitude of $>$ ca. 7.5 to generate seismogenic tsunami (Bryant, 2001). However, with the exception of the Lisbon earthquake, the size of the historic earthquakes reviewed here, which appear to have generated hazardous affects, possessed estimated magnitudes below this threshold. This threshold has led some authors to discredit the historical accounts that suggest, for example, the 1580 earthquakes generated the 'giant' waves simply because "the earthquake would seem too small to generate significant tsunami even in the immediate vicinity" (McGuire, 2005, p. 41). This type of view has prejudiced an evaluation of the event leading authors to invoke confusion with flooding due to a storm a year later in 1581 (e.g. Musson, 2007) despite the publication of contradictory contemporary accounts prior to the storm. Similarly, without giving any reasons, Skipp et al. (1985) consider the account

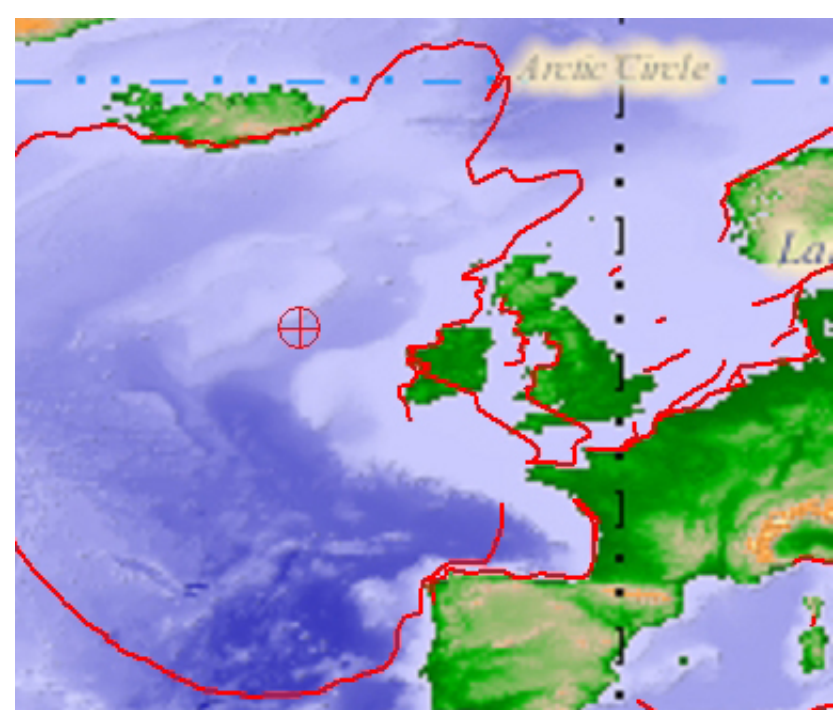

Fig. 5. Preliminary Joint Research Centre model output for tsunami propagation around the coasts of Europe from a source in the North Atlantic. Red lines indicate tsunami travel time in $2 \mathrm{~h}$ intervals.

of the sea rushing in over marshes on Mersea Island during the 1884 Colchester earthquake, published only a day later, is probably an exaggeration.

It is helpful to set these earthquakes and their resulting effects in a global context. One of the most definitive databases on tsunami is maintained by NOAA's National Geophysical Data Center (2007). It contains a record of 1610 tsunami from $2000 \mathrm{BC}$ to the present. Surprisingly, $50 \%$ of earthquakes with a magnitude below 7.1 generated identifiable tsunami. Only 53 earthquakes with a magnitude of 5.8 or less-covering the range of earthquakes described in this study-produced tsunami. Measurements exist for only 33 of these events. This represents only $2 \%$ of known events. Despite the paucity of detail, some of these small earthquakes have produced tsunami equivalent in size to those described above. Eleven of the events generated tsunami that reached more than $1.0 \mathrm{~m}$ above sea level. Two earthquakes with surface magnitudes, $\mathrm{M}_{S}$, of 5.2 and 4.5 are noteworthy in the context of this study of Britain. They produced tsunami reaching $6.1 \mathrm{~m}$ and $1 \mathrm{~m}$ respectively above sea level. The first occurred at Santa Monica in Southern California on $31 \mathrm{Au}-$ gust 1930 (Lander et al., 1993), while the latter occurred in Hawaii on 18 March 1952 (Lander and Lockridge, 1989).

The 5.2 magnitude Californian earthquake had an epicenter offshore in Santa Monica Bay, which is thought triggered a submarine slide in an offshore seabed channel that generated the tsunami and, therefore, has similarities with the Dover Straits physical setting and events (see below). The ca. $6 \mathrm{~m}$ high tsunami was only observed in the local area where one person drowned and 16 others had to be rescued from the surf; the tsunami did not register on either the Santa Barbara or San Diego tide gauges located ca. $100 \mathrm{~km}$ north 
and south along the coast respectively. The 4.5 magnitude earthquake in Hawaii appears similar to the Colne, Thames and Milford Haven tsunamis described here, although both of these British events were of a higher magnitude. A ca. $1 \mathrm{~m}$ high tsunami came ashore at Kalapana at about 6 p.m. (local time), overtopped a barrier dune and passed inland for about $180 \mathrm{~m}$; however, no damage is reported. There is no suggestion that a submarine slide was involved and, therefore, the tsunami was triggered by a seismic mechanism, although rupture of the sea-floor is unlikely given the low-magnitude of the earthquake. Again, the effect was local as the tide gauge at Hilo, ca. $50 \mathrm{~km}$ along the coast, did not register the tsunami. These examples both demonstrate that relatively low-magnitude earthquakes can lead to relatively large local tsunami.

These examples from California and Hawaii, although instructive, are not entirely analogous with the British events reviewed here as they are located in plate boundary and volcanic regions respectively. However, a recent evaluation of tsunami in the Adriatic Sea, a generally shallow water - intraplate setting, shows that intense local tsunami have been generated historically by earthquakes typically with magnitudes less than 6 (Paulatto et al., 2007). They also report that tsunamigenic earthquake epicentres have been located inland as well as offshore. Their models predict the generation of small tsunami that become amplified enough, by local coastal morphology, to inundate the coast and cause damage, and that shallow earthquakes are more capable of generating tsunami than those with a greater focal depth. They also demonstrate that tsunami excited by inland earthquakes propagate away from the shore as appears to have happened in the Colne Estuary during the 1884 Colchester earthquake. The Italian Tsunami Catalogue recognises approximately 70 mostly seismogenic tsunami, but the largest earthquake in the Italian Seismic Catalogue has a magnitude of 7.4, therefore, the majority of these tsunami were generated by lower magnitude seismic events (Tinti et al., 2004). Elsewhere in the Mediterranean, tsunami generation by relatively lowmagnitude earthquakes is common (e.g. Papadopoulos and Chalkis, 1984).

Other examples of low-magnitude, but nevertheless tsunamigenic earthquakes, have been described from Asia (Didenkulova and Pelinovsky, 2006). Of note here are two 3.7 magnitude earthquakes that generated tsunami in river and coastal settings, the first occurred in the River Volga on 12 September 1806 where deliberate oscillations in the water were noticed (Tatevosyan and Mokrushina, 2003), and more recently on the 5 January 1992 in Tonkin Bay (China) where a 3.7 magnitude earthquake generated $0.8 \mathrm{~m}$ high tsunami that caused damage to fishing boats (Lin Ye et al., 1993; Lander et al., 2003). These further examples demonstrate that, although relatively rare, low-magnitude earthquakes can result in the generation of local tsunami.

\subsection{Seismic surface waves and tsunami}

It appears that near-coastal, relatively shallow-water, earthquakes have the potential to cause seabed deformation and so generate local tsunami even at low magnitudes, and that this risk should not be discounted out of hand. In smallenclosed bodies of water or narrow channels such as estuaries and rivers, ground motions induced by a combination of Love and Rayleigh waves can cause seiching or sloshing of water and excite tsunami. Love waves produce a shearing motion in the horizontal plane, while Rayleigh waves generate elliptical motion in the vertical plane similar to the propagation of ocean waves (Bryant, 2005). In open water, theoretical work indicates that some earthquakes in shallow, unconsolidated sediment rupture slowly producing large lowfrequency gravity waves that form tsunami at the ocean surface (Houston, 1999; Novikova et al., 2000). However, slow rupturing should not generate a tsunami below an earthquake magnitude of 7.0 because observed slip displacements are less than $0.5 \mathrm{~m}$ (Geist, 1997). There is no known evidence of any surface rupturing with the earthquakes described here, and that deformation may be due, in some cases, to the submarine progression of ground waves.

The magnitude of vertical ground motion is poorly researched with little attention given to their tsunamigenic potential. Noteworthy are measured vertical ground motions exceeding $100 \mathrm{~cm}$ for the $\mathrm{M}_{w}$ 7.9-magnitude Denali earthquake of 3 November 2002 in Alaska (Porter and Leeds, 2000), and $23.5 \mathrm{~cm}$ for the $\mathrm{M}_{w}$ 6.7-magnitude Northridge earthquake of 17 January 1994 (Ellsworth et al., 2004). These ground motions are not fault displacements, but ground oscillations related mainly to the passage of Rayleigh seismic waves. Also of interest is seafloor movement and tsunami generation due to underground nuclear explosions, for example, bomb tests on Amchitka Island in Alaska resulted in local seafloor oscillations of up to $0.56 \mathrm{~m}$ (Olsen et al., 1972). Furthermore, model predictions show that earthquake-induced seabed oscillations (cf. ground waves) can generate tsunami with an amplitude dependent upon the spatial distribution, velocity and duration of the bottom oscillations (Nosov and Skachko, 2001). A given example indicates that bottom oscillations over a $60 \mathrm{~s}$ period with a velocity of $10 \mathrm{~m} / \mathrm{s}$ can generate tsunami up to $0.8 \mathrm{~m}$ high.

More relevant to Britain is the study of smaller, shallow earthquakes in Greece (Carydis, 2004). Here, the effects of vertical motion are independent of earthquake magnitude. Earthquakes with magnitudes as low as 4.2 generate sufficient vertical motion to cause substantial building destruction. Estimates put the amplitude of the vertical motion for these small earthquakes at $8 \mathrm{~cm}$. While this amplitude appears small, similar uplift of the seabed in confined bodies of water could generate tsunami that can not only cause noticeable effects, but also explain some of the reports of tsunami following small earthquakes (e.g. Paulatto et al., 2007). Ground waves associated with the 1884 Colchester 
earthquake are estimated to have been larger than this, which may be due to its shallow epicenter. Indeed, Walker and Musson (2007) draw similarities between the 1884 Colchester earthquake and the most recent Dover Straits (local magnitude, $\mathrm{M}_{L}$, of 4.2) earthquake, that of 28 April 2007 at Folkestone, stating "the shallow depth [ca. $2 \mathrm{~km}$ ] of both earthquakes in a "soft" geological environment, resulting in a concentration (and possibly amplification) of the groundshaking in their epicentral areas" that causes much damage (p. 6).

Such low magnitude earthquakes, with shallow epicenters and in certain geological settings, could be amplified and capable of effects normally associated with higher magnitude earthquakes. For example, Musson (1998) remarks, liquefaction was observed during the Barrow-in-Furness (NW England) earthquake of 15 February 1865 with a local magnitude, $\mathrm{M}_{L}$, no greater than 3.5. As with tsunami, liquefaction is usually associated with relatively large magnitude earthquakes and Musson (1998) attributes this occurrence to a shallow epicentre.

\subsection{Possibility of submarine slides}

Ground waves have been observed in connection with the 1580 Dover Straits earthquake and, as mentioned above, the 1884 Colchester earthquake. However, whereas the tsunami associated with the 1884 event are a similar magnitude to the observed ground waves, flooding apparently caused by the 1580 event appears to be far more severe than can easily be conceived as due to ground waves alone.

Bathymetric work has recently culminated in quite complex seabed topography of the Dover Straits (Gupta et al., 2007), comprising a prominent escarpment overlying the shear zone. This is cut by a relatively deep palaeochannel system, known as the Loburg Channel in the Dover Straits, with some channels unfilled by sediment and bounded in places by composite scarps up to $40 \mathrm{~m}$ high. The presence of relatively steep slopes within the English Channel presents the possibility that tsunami may have been triggered by submarine slides which, given the descriptions of coastal cliff collapse during historic earthquakes (e.g. 1580), is plausible.

Cliff collapse may also occur independently of seismic activity, which could result in 'phantom' tsunami, such as that of 1381 at Dover. A recent example occurred at Beachy Head, a chalk cliff on the Sussex coast, which collapsed in January 1999, bringing down with it a conservatively estimated $60 \mathrm{~m}$ high and $15 \mathrm{~m}$ thick slab of chalk comprising $150000 \mathrm{~m}^{3}$ of rock (Haslett, 2000; Mortimore and Duperret, 2004). When compared to the volume of slumps that have generated tsunami elsewhere, such as a $13000 \mathrm{~m}^{3}$ slump that generated a $0.4 \mathrm{~m}$ high tsunami in Monterey Bay (USA) in 1989 (Ma et al., 1991), then it is conceivable that a submarine slump in the Dover Straits approaching the proportions to that of the Beachy Head failure may generate locally a significantly higher tsunami. Also, slumping can initiate close to the coast, as Assier-Rzadkiewicz et al. (2000) examine the case of artificial landfill that slumped into the Mediterranean during the construction of Nice Airport in southern France (16 October 1979) that generated tsunami locally over $3 \mathrm{~m}$ high inundating the nearby city of Antibes. However, tsunami attenuated rapidly away from the slump area due to strong wave dispersion so, as with some other landslidegenerated tsunami, the effect was restricted locally.

It is also worth considering submarine slides in estuarine or embayment settings as recent research has suggested that earthquake-triggered mud slides on relatively low-relief lake floors, leaving $9 \mathrm{~m}$ high scars, have generated tsunami 3-4 m high (Schnellmann et al., 2004). Evidence was presented earlier for the disturbance of anoxic muddy bottom sediments in the Colne Estuary by the 1884 Colchester earthquake, so the possibility of mudslides here cannot be ruled out.

\section{3 "Phantom" tsunami}

A number of unusual historic wave events dismissed by Long and Wilson (2007) as being "non-tsunami" in origin (e.g. $1759,1811,1843,1859,1869)$ may in fact be "phantom" tsunami generated by submarine slides unrelated to significant seismic activity. Very low magnitude earthquakes have been linked to submarine slides and tsunami generation elsewhere, such as a magnitude 3 earthquake that triggered a slump generating a $6 \mathrm{~m}$ high tsunami in the Gulf of Corinth, Greece, on 7 February 1963 (Papadopoulos et al., 2007). The 1607 flood in the Bristol Channel and Severn Estuary may be another. It occurred rapidly at around 9am on 30 January coincident with a high spring tide (high water at 8.32 a.m. at Burnham-on-Sea, Somerset) when the tide would probably be more or less level with the top of the sea banks. Although meteorological reports are contradictory, some accounts suggest that the day was "fayrely and brightly spred" (Bryant \& Haslett, 2003, p. 164), whilst others report stormy conditions (Horsburgh \& Horritt, 2006), Disney (2005) states that "there is a second-hand report of an earth tremor felt earlier that morning", a view that is also held by Witts (2002) who suggests the 1607 flood "was caused by an earthquake somewhere out in the Atlantic" (p. 100).

If an earthquake, even of relatively low magnitude, had occurred and directly, or indirectly (i.e. through triggering a submarine slide), generated a tsunami that arrived at the coast coincident with high tide, it is likely this would have raised water levels above the top of the sea banks and caused flooding. Furthermore, the coincidence of a high spring tide, and perhaps the suggested stormy conditions of some authors, could raise the likelihood of an earthquake occurring. The passage of an intense low-pressure cell over a shallow shelf can induce a change in load on the Earth's crust of 10 mil t km ${ }^{-2}$ over a matter of hours (Bryant, 2005). In areas where the Earth's crust is under strain, this pressure change due to ocean loading may be sufficient to trigger tectonic activity. Ocean loading is not well-understood but has been 
linked to volcanic activity in Alaska (McNutt, 1999), seasonality of earthquake occurrence in the Philippine Sea (Ohtake and Nakahara, 1999), and with the Tokyo earthquake of 1 September 1923 (Bryant, 2005). In the Caribbean and Central America, the coincidence of earthquakes and cyclones has a higher probability of occurrence than the joint probability of each event separately (Bryant, 2005).

\subsection{Tidal relationship}

It also appears from the historic records that most, if not all, of the earthquakes discussed here occurred within two hours of high tide (Table 1). Such a seismic-tidal relationship is reasonably well-known (e.g. Tsuruoka et al., 1995) and has been observed elsewhere, for example, seismic activity related to the 26 December 2004 earthquake in Indonesia responsible for the Indian Ocean tsunami was in phase with tidal cycles (Crockett et al., 2006). It is likely that increased ocean loading associated with a rising tide, particularly in the meso-macrotidal setting of northwest Europe, may trigger an earthquake where the Earth's crust is under strain. Indeed, the 2007 Folkestone earthquake also occurred within ca. 30 min of high tide. Any tsunami generated, even a small one, would be more likely to be noticed around high tide and, indeed, be more damaging.

\section{Conclusions}

This study has considered a number of tsunami-like occurrences affecting the coast of Britain during the past $1000 \mathrm{yrs}$. Four groups have been established that treat together similar events:

1. Dover Straits events: seismic activity occurs frequently in the Dover Straits and descriptions of tsunami-like occurrences are associated with events in AD 1247, 1382, 1449, 1580, 1776, and 1831. Another event, described as a "waterquake", but not linked with an earthquake, was experienced at Dover in 1381. Earthquake magnitudes up to ca. 6 have been estimated for some of these events, but even if this magnitude is too low to rupture the seabed, ground waves did occur during some earthquakes that may have displaced the seabed. A complex bathymetry comprising submarine channels and escarpments up to $40 \mathrm{~m}$ high may have provided sites for undersea slides. Slides not linked to earthquakes may explain "phantom" tsunami, such as that in 1381.

2. Far-field tsunami: a number of confirmed tsunami have come ashore in Britain due to far-field earthquakes, such as along the Azores-Gibraltar Fracture Zone in AD 1755, 1761, 1802, 1941, 1969, and 1975, the Chilean earthquake of 1960, and the Indian Ocean tsunami of 2004. Closer to the British Isles, tsunamilike waves have been linked to earthquakes with epicen- tres located offshore southwest England and the North Sea in 1847 and 1927 respectively.

3. Near-coastal low-magnitude seismic events: relatively low-magnitude earthquakes with epicentres in nearcoastal settings generated small tsunami on at least two occasions, in 1884 in eastern England (4.6 - 5.5 $\mathrm{M}_{L}$, Colne and Thames estuaries) and 1892 in South Wales (5.1 $\mathrm{M}_{L}$, Milford Haven). A mechanism for tsunami generation is problematic in these cases, but substantial ground waves were observed in the 1884 event that would have led to impulsive displacement of the seabed locally, which elsewhere have been linked to intense tsunami (Paulatto et al., 2007). Sea disturbance associated with a small earthquake (local magnitude, $\mathrm{M}_{L}, 4.0$ ) was also observed in 1859 in southwest England that may indicate the sensitivity of shallow water settings to small near-coastal earthquakes. It has been suggested that some of these earthquakes have shallow epicentres that may amplify their effects and so take on the characteristics of a higher magnitude event.

4. Cosmogenic tsunami: this category contains only one event that of AD 1014 when widespread flooding occurred in southeast England, Cornwall and possibly Cumbria. It has been suggested that this flooding event is a tsunami linked to a comet impact as indicated by GRIP ice core records and Chinese astronomy (Baillie, 2007). Although speculative at this stage, compelling combined historic and physical evidence persuades that an in-depth investigation should be made of this event.

The fact that historical records reviewed here describe tsunami-like occurrences is not doubted, but whether these events are tsunami, or not, is in question. Some events have been confirmed as tsunami, but for others the link to a tsunamigenic trigger is unclear. Even for those associated with an earthquake, the magnitude is usually lower than is conventionally considered to be able to generate a tsunami, and yet tsunami-like activity is reported. We have discussed possible triggering mechanisms for generating tsunami under such conditions, which have been shown to link lowmagnitude earthquakes and tsunami elsewhere. It is clear that each event reviewed in this study warrants further detailed investigation and should not be discounted out of hand simply because the circumstances are problematic under current tsunami theory.

Acknowledgements. We are grateful to Bill McGuire (Benfield Hazard Research Centre, UCL), Anna Fokaefs, and anonymous reviewers for constructive comments on earlier versions of this paper, to Bath Spa University for funding field and archive work, and to Lesley Howard Languages for the French translation of Discourse (1580).

Edited by: S. Tinti

Reviewed by: A. Fokaefs and another anonymous referee 


\section{References}

Ambraseys, N. and Melville, C.: Seismicity of the British Isles and the North Sea. SERC Marine Technology Centre, Imperial College, London, 132 pp., 1983.

Assier-Rzadkiewicz, S., Heinrich, P., Sabatier, P. C., Savoye, B., and Bourillet, J. F.: Numerical modelling of a landslidegenerated tsunami: the 1979 Nice event, Pure and Applied Geophysics, 157, 1707-1727, 2000.

Baillie, M.: The case for significant numbers of extraterrestrial impacts through the late Holocene, J. Quat. Sci., 22, 101-109, 2007.

Boys, W.: Collections for an history of Sandwich in Kent. Vol. 2, Canterbury, 1792.

Bryant, E. A.: Tsunami: the underrated hazard. Cambridge, Cambridge University Press, 2001.

Bryant, E. A.: Natural Hazards. 2nd ed. Cambridge, Cambridge University Press, 2005.

Bryant, E. A. and Haslett, S. K.: Was the AD 1607 coastal flooding event in the Severn Estuary and Bristol Channel (UK) due to a tsunami? Archaeology in the Severn Estuary 13 (for 2002), 163167, 2003.

Bryant, E. A. and Haslett, S. K.: Catastrophic wave erosion, Bristol Channel, UK - impact of tsunami?, J. Geol., 115, 253-269, 2007.

Carydis, P. G.: The effect of the vertical earthquake motion in near field, in: Structures under shock and impact VIII, edited by: Jones, N. and Brebbia, C., WIT Press, 267-282, 2004.

Clark, J. E.: The Essex Earthquake. The Natural History Journal and School Reporter, 8, 85-86, 1884.

Colchester Gazette: The Gazette, The Colchester Gazette, 23 April, p. 2,1884

Crockett, R. G. M., Gillmore, G. K., Phillips, P. S., and Gilbertson, D. D.: Tidal synchronicity of the 26th December 2004 Sumatran earthquake and its aftershocks, Geophys. Res. Lett., 33, L19302, doi:10.1029/2006GL027074, 2006

Daily News: Earthquake shocks in England, Wales, and Ireland. Daily News, 19 August, p. 6, 1892.

Davison, C.: A history of British earthquakes. Cambridge University Press, Cambridge, 1924.

Dawson, A. G., Musson, R. M. W., Foster, I. D. L., and Brunsden, D.: Abnormal historic sea-surface fluctuations, SW England, Mar. Geol., 170, 59-68, 2000.

DEFRA (Department for Environment, Food and Rural Affairs): The threat posed by tsunami to the UK, London, HMSO, 2005.

DEFRA (Department for Environment, Food and Rural Affairs): Tsunamis - assessing the hazard for the UK and Irish Coasts, London, DEFRA, 2006.

Didenkulova, I. I. and Pelinovsky, E. N.: Phenomena similar to tsunami in Russian internal basins, Russian Journal of Earth Sciences, 8, ES6002, doi:10.2205/2006ES000211, 9 pp., 2006.

Discourse: Discours d'une merveilleuse et veritable copie du grand deluge, 1580, J. Coquerel, Paris, 1580.

Disney, M.: An Atlantic tsunami created our greatest environmental disaster, and it could happen again, The Times, 4 January 2005.

Douglas, C. K. M.: The Line-Squall and Channel Wave of 20 July 1929, Meteorol. Mag., 64, 187-189, 1929.

Earthquake Engineering Research Centre: Lisbon quake affects Netherlands. 18th century copper engraving in the Jan Kozak Collection, Cataloque no. KZ146 (available at http://nisee. berkeley.edu/elibrary/Image/KZ146, accessed 20 July 2007), 2005.
Edmonds, R.: On extraordinary agitations of the sea not produced by winds or tides, Transactions of the Devonshire Association, 3, 144-152, 1869.

Ellart, G. and Vion, A.: Documents sur le tremblement de terre du 6 Avril 1580, Bull. de la Comm. de d'hist. et d'arch. du Pas-deCalais 12, 540-550, 1991.

Ellsworth, W. L., Celebi, M., Evans, J. R., Jensen, E. G., Kayen, R., Metz, M. C., Nyman, D. J., Roddick, J. W., Spudich, R., and Stephens, C. D.: Near-field ground motion of the 2002 Denali Fault, Alaska, earthquake recorded at Pump Station 10, Earthq. Spectra, 20, 597-615, 2004.

Evening Standard: The Earthquake. The Evening Standard, 25 April, p. 2, 1884.

Fitch, A.: The earthquake, The Leeds Mercury, 25 April, p. 8, 1884.

Foster, I. D. L., Albon, A. J., Bardell, K. M., Fletcher, J. L., Jardine, T. C., Mothers R. J., Pritchard, M. A., and Turner, S. E.: High energy coastal sedimentary deposits: an evaluation of depositional processes in southwest England, Earth Surf. Proc. Land., 16, 341-356, 1991.

Foster, I. D. L., Dawson, A. G., Dawson, S., Lees, J. A., and Mansfield, L.: Tsunami sedimentation sequences in the Scilly Isles, south-west England, Science of Tsunami Hazards, 11, 35-45, 1993.

Freeman's Journal: An earthquake visitation. Freeman's Journal and Daily Commercial Advertiser, 20th August, p. 5, 1892.

Gairdner, J.: Anne of Bohemia (1366-1394). In The Compact Edition of the Dictionary of National Biography, Oxford University Press, Oxford, 35-36 [420-423 of the original microfiche text], 1975.

Geist, E. L.: Local tsunamis and earthquake source parameters, Adv. Geophys., 39, 117-209, 1997.

Green, B.: New Shoreham. Sussex Archaeological Collections XXVII (available from http://shoreham.adur.org.uk/new shoreham.htm, accessed 4 April 2007), 1877.

Gupta, S., Collier, J. S., Palmer-Felgate, A., and Potter, G.: Catastrophic flooding origin of shelf valley system in the English Channel, Nature, 448, 342-345, 2007.

Haining, P.: The great English earthquake, NEL Books, London, 1976.

Haslett, S. K.: Coastal Systems, Routledge, London, 2000.

Haslett, S. K. and Bryant, E. A.: The AD 1607 coastal flood in the Bristol Channel and Severn Estuary: historical records from Devon and Cornwall (UK), Archaeology in the Severn Estuary, 15 (for 2004), 81-89, 2005.

Haslett, S. K. and Bryant, E. A.: Reconnaissance of historic (postAD 1000) high-energy deposits along the Atlantic coasts of southwest Britain, Ireland and Brittany, France, Mar. Geol., 242, 207-220, 2007a.

Haslett, S. K. and Bryant, E. A.: Evidence for historic coastal highenergy wave impact (tsunami?) in North Wales, United Kingdom, Atlantic Geol., 43, 137-147, 2007b.

Healy, M. G.: The lithostratigraphy and biostratigraphy of a Holocene coastal sediment sequence in Marazion Marsh, west Cornwall, UK with reference to relative sea-level movements, Mar. Geol., 124, 237-252, 1995.

Healy, M. G.: Field sites: Marazion Marsh (SW 510 315) and Hayle Estuary at Copperhouse (SW 566 380). Holocene evolution at Marazion Marsh and Hayle Copperhouse, west Cornwall, in M. G. Healy (Ed.) IGCP Project 367, Late Quaternary Coastal 
Change in West Cornwall, UK - Field Guide. Environmental Research Centre, University of Durham, Research Publication, 3, 46-59, 1996.

Holinshed, R.: Chronicles of England, Scotland and Ireland (2nd Ed), vol. 1-3, J. Harison, London, 1587.

Holinshed, R.: Chronicles of England, Scotland and Ireland (6 vol. edition), London, 1808.

Horsburgh, K. and Horritt, M.: The Bristol Channel floods of 1607 - reconstruction and analysis, Weather, 61, 272-277, 2006.

Houston, H.: Slow ruptures, roaring tsunamis, Nature, 400, 409, 1999.

Ingram, J.: The Anglo-Saxon Chronicle, World Wide School, Seattle (available athttp://www.worldwideschool.org/library/books/ hst/english/TheAnglo-SaxonChronicle/legalese.html, accessed 3 April 2007), 1823.

Johnson, W. F.: History of the Johnstown Flood, Edgewood Publishing Co., Pennsylvania (available at http://prr.railfan. net/documents/JohnstownFlood.html, accessed on 4 September 2007), 1889.

Johnston, A. C.: Seismic moment assessment of earthquakes in stable continental regions-III, New Madrid 1811-1812, Charleston 1886 and Lisbon 1755, Geophys. J. Int., 126, 314-344, 1996.

Kent News: Dave the dolphin tried to warn swimmers off Sandgate, Kent News, accessed online at http://www.kentnews.co.uk/(kentnews/Dave-the-dolphin-tried-to-warn-swimmers-off-Sandgatenewsinkent3640.aspx) on 30 April 2007, 2007.

Kentish Gazette: Dover, March 7 - Earthquake! Kentish Gazette, 8 March, p. 2, 1831.

Lander, J. F. and Lockridge, P. A.: United States tsunamis (including United States possessions) 1690-1988, National Oceanic and Atmospheric Administration, National Geophysical Data Center, Boulder, Colorado, USA, Publication 41-2, 265 pp., 1989.

Lander, J. F., Lockridge, P. A., and Kozuch, M. J.: Tsunamis affecting the West Coast of the United States, 1806-1992, National Oceanic and Atmospheric Administration, National Geophysical Data Center, Boulder, Colorado, USA, KGRD No. 29 (September), 242 pp., 1993.

Lander, J., Whiteside, L., and Lockridge, P.: Two decades of global tsunamis 1982-2002, Science of Tsunami Hazards, 21, 3-88, 2003.

Leenders, K. A. H. W.: The Lisbon 1755 earthquake felt in Breda (NL), Engelbrecht van Nassau 19, p. 92 (also available at http://users.bart.nl/ leenders/txt/dein-uk.html, accessed 20 July 2007), 2000.

Lin, Y., Xinian, W., and Chenlan, B.: Tsunami in the China Seas and its warning system, Tsunami 93: Proceedings of the IUGG/IOC International Tsunami Symposium, Wakayama, Japan, 771-777, 1993.

Liverpool Mercury: Liverpool Mercury, 28 April, p. 5, 1884.

Long, D. and Wilson, C. K.: A catalogue of tsunamis in the UK, British Geological Survey, Marine, Coastal and Hydrocarbons Programme Commissioned Report CR/07/077, 2007.

Lowes, J. L.: The Tempest at hir Hoom-Cominge, Modern Language Notes, 19, 240-243, 1904.

Lowes, J. L.: The date of Chaucer's Troilus and Criseyde, PMLA, 23, 85-306, 1908.

Ma, K., Satake, K. and Hiroo, K.: The origin of the tsunami excited by the 1989 Loma Prieta earthquake - faulting or slumping?, Geophys. Res. Lett., 18, 637-640, 1991.
Mansergh, J. F.: Earthquake, 1580, Oxford University Press, Oxford, 1891.

Martin, G. H. (Ed.): Knighton's Chronicles 1337-1396, Clarendon Press, Oxford, 593 pp., 1995.

Masson, D. G.: Catastrophic collapse of the volcanic island of Hierro $15 \mathrm{ka}$ ago and the history of landslides in the Canary Islands, Geology, 24, 231-234, 1996.

McGuire, B.: Swept Away. New Sci., 38-42, 2005.

McNutt, S. R.: Eruptions of Pavlof Volcano, Alaska, and their possible modulation by ocean load and tectonic stresses: reevaluation of the hypothesis based on new data from 1984-1998, Pure and Applied Geophysis, 155, 701-712, 1999.

Meldola, R. and White, W.: Report on the East Anglia earthquake of April 22, 1884, Essex Field Club Special Memoirs, 1, 1-228, 1885 .

Melville, C.: The historical seismicity of England, Disasters, 5, 369-376, 1981.

Melville, C.: The seismicity of England: the earthquake of May 21, 1382, Bollettino di Geofisica Teorica ed Applicata, 24, 129-133, 1982.

Melville, C. P., Levret, A., Alexandre, P., Lambert, J., and Vogt, J.: Historical seismicity of the Straight of Dover - Pas de Calais, Terra Nova, 8, 626-647, 1996.

Miloh, T., Tyvand, P. A., and Zilman, G.: Green functions for initial free-surface flows due to 3D impulsive bottom deflections, J. Eng. Math., 43, 57-74, 2002.

Montserrat, S., Vilibić, I., and Rabinovich, A. B.: Meteotsunamis: atmospherically induced destructive ocean waves in the tsunami frequency band, Nat. Hazards Earth Syst. Sci., 6, 1035-1051, 2006 ,

http://www.nat-hazards-earth-syst-sci.net/6/1035/2006/.

Mortimore, R. N. and Duperret, A.: Coastal Chalk Cliff Instability, Geological Society of London, Engineering Geology Special Publication No. 20, 184 pp., 2004.

Munday, A.: A view of sundry examples, William Wright, London, 32pp., 1580.

Musson, R. M. W.: Seismicity of Cornwall and Devon, BGS Global Seismology Report, No. WL/89/11, 1989.

Musson, R. M. W.: British Geological Survey Global Seismology Report, No. WL/94/04, 1994.

Musson, R. M. W.: The Barrow-in-Furness earthquake of 15 February 1865: liquefaction from a very small magnitude event, Pure Appl. Geophys., 152, 733-745, 1998.

Musson, R.: Fatalities in British earthquakes, Astronomy and Geophysics, 44(1), 14-16, 2003.

Musson, R. M. W.: Undead earthquakes, Journal of Seismology, 9, 111-114, 2005.

Musson, R. M. W.: The enigmatic Bala earthquake of 1974, Astronomy and Geophysics, 47(5), 11-15, 2006.

Musson, R. M. W.: British earthquakes, Proc. Geol. Ass., 118, 305337, 2007.

Musson, R. M. W., Neilson, G., and Burton, P. W.: Macroseismic reports on historical British earthquakes XIV: 22 April 1884 Colchester, British Geological Survey Global Seismology Report, No. WL/90/33, 1990a.

Musson, R. M. W., Neilson, G., and Burton, P. W.: British Geological Survey Global Seismology Report, No. WL/90/33, 1990b.

Myers, J.: History of legal time in Britain, Available at http://www. srcf.ucam.org/ jsm28/british-time/, accessed 5 April 2007, 
2007.

Mynors, R. A. B., Thomson, R. M., and Winterbottom, M.: William of Malmesbury: the history of the English kings, vol. 1, Clarendon Press, Oxford, 1998.

National Geophysical Data Center: Tsunami Event Database, http: //www.ngdc.noaa.gov/nndc/struts/form?t=101650\&s=7\&d=7, 2007.

Neilson, G., Musson, R. M. W. and Burton, P. W.: The "London" earthquake of 1580 April 6, Eng. Geol., 20, 113-142, 1984.

NERC: United Kingdom digital marine atlas, Swindon, Natural Environment Research Council for Great Britain, 1991.

Nosov, M. A. and Skachko, S. N.: Nonlinear tsunami generation mechanism, Nat. Hazards Earth Syst. Sci., 1, 251-253, 2001, http://www.nat-hazards-earth-syst-sci.net/1/251/2001/.

Nott, J. F.: Waves, coastal boulder deposits and the importance of the pre-transport setting, Earth Planet. Sc. Lett., 210, 269-276, 2003.

Nowlan, Alden, Nine Micmac Legends, Lancelot Press, Hantsport (Nova Scotia), 1983.

Novikova, T., Wen, K.-L., and Huang B.-S.: Amplification of gravity and Rayleigh waves in a layered water-soil model, Earth Planets Space, 52, 579-586, 2000.

Ohtake, M. and Nakahara, H.: Seasonality of great earthquake occurrence at the northwestern margin of the Philippine Sea Plate, Pure and Applied Geophysics, 155, 689-700, 1999.

Olsen, K. H., Stewart, J. N., McNeil, J. E., and Vitousek, M. J.: Long-period water-wave measurements for the MILROW and CANNIKIN nuclear explosions, B. Seismol. Soc. Am., 62, 1559-1578, 1972.

Papadopoulos, G. A. and Chalkis, B. J.: Tsunamis observed in Greece and the surrounding area from antiquity up to the present times, Marine Geology, 56, 309-317, 1984.

Papadopoulus, G. A., Daskalaki, E., Fokaefs, A., and Giraleas, N.: Tsunami hazards in the Eastern Mediterranean: strong earthquakes and tsunamis in the East Hellenic Arc and Trench system, Nat. Hazards Earth Syst. Sci., 7, 57-64, 2007, http://www.nat-hazards-earth-syst-sci.net/7/57/2007/.

Paulatto, M., Pinat, T., and Romanelli, F.: Tsunami hazard scenarios in the Adriatic Sea domain, Nat. Hazards Earth Syst. Sci., 7, 309 325,2007 , http://www.nat-hazards-earth-syst-sci.net/7/309/2007/.

Penny Illustrated: Earthquakes as usual, The Penny Illustrated, 27 August, p. 6, 1892.

Porter, L. D. and Leeds, D. J.: Correlation of strong ground motion for the 1994 Northridge earthquake, Geophys. J. Int., 143, 376388,2000

Ritchie, C.: The sea ceased to ebb and flow, Kent Seen, 3(6), 36-37, 1991.

Saundry, J. W.: Saundry's "One and All" Almanack. John W. Saundry, Penzance (available from http://west-penwith.org.uk/ pztime.htm, accessed 3 April 2007), 1936.
Schnellmann, M., Anselmetti, F. S., Giardini, D., McKenzie, J. A., and Ward, S. N.: Ancient earthquakes at Lake Lucerne, American Scientist, 92, 46-53, 2004.

Scott, R. F.: The Essex earthquake of 1884, Earthquake Engineering and Structural Dynamics, 5, 145-155, 1977.

Short, T.: A general chronological history of the air, weather, seasons, meteors, etc., Longman \& Miller, London, 1749.

Skipp, B. O., Shilston, D. T., Gutmanis, J. C., and Adams, R. D.: Colchester revisted, In Institute of Civil Engineering: Earthquake Engineering in Britain, Thomas Telford Ltd, London, 189-206, 1985.

Smith, D. E., Shib, S., Cullingford, R. A., Dawson, A. G., Dawson, S., Firth, C. A., Foster, I. D. L., Fretwell, P. T., Haggart, B. A., Holloway, L. K., and Long, D.: The Holocene Storegga Slide tsunami in the United Kingdom, Quat. Sci. Rev., 23, 2291-2321, 2004.

Tatevoysan, R. E. and Mokrushina, N. G.: Historical seismicity of Middle Volga region, Izvestiya, Physics of the Solid Earth, 39, 189-215, 2003.

The Times: Natural phenomenon, The Times, 28 May, p. 6, 1847.

The Times: Earthquake shocks, The Times, 19 August, p. 4, 1892a.

The Times: The Weather, The Times, 19 August, p. 4, 1892b.

Tinti, S., Maramai, A., and Graziani, L.: The new catalogue of Italian tsunamis, Nat. Hazards Earth Syst. Sci., 33, 439-465, 2004, http://www.nat-hazards-earth-syst-sci.net/33/439/2004/.

Tsuruoka, H., Ohtake, M., and Sato, H.: Statistical test of the tidal triggering of earthquakes: contribution of the ocean tide loading effect, Geophys. J. Int., 122, 183-194, 1995.

Tyrell, G.: Recent Scottish earthquakes. Transactions of the Geological Society of Glasgow, 9, 1-41, 1932.

Varley, P. M.: Seismic risk assessment and analysis, in: Engineering geology of the Channel Tunnel, edited by: Harris, C. S., Hart, M. B., Varley, P. M., and Warren, C. D., Telford, London, 194-216, 1996.

Walker, A. and Musson, R.: Kent rocked, Geoscientist, 17(6), 6, 2007.

Ward, S. N. and Day, S. J.: Cumbre Vieja volcano - potential collapse and tsunami at La Palma, Canary Islands, Geophys. Res. Lett., 28, 3397-3400, 2001.

Witts, C.: Disasters on the Severn, Tempus Publishing Ltd, Stroud, 160 pp., 2002.

Wood, A.: The history and antiquities of the University of Oxford, Vol. 2/i, Oxford, 1796.

Yanovskaya, T. B., Romanelli, F., and Panza, G. F.: Tsunami excitation by inland/coastal earthquakes: the Green function approach, Nat. Hazards Earth Syst. Sci., 3, 353-365, 2003, http://www.nat-hazards-earth-syst-sci.net/3/353/2003/. 